\title{
THE EFFECTIVENESS OF SOCRATIVE APPLICATION FOR FORMATIVE ASSESSMENT IN TEACHING VOCABULARY AT SMA MUHAMMADIYAH 1 PONOROGO
}

\author{
Fitriani Nurhasanah; Nurul Khasanah \\ Institut Agama Islam Negeri Ponorogo (IAIN Ponorogo) \\ fitrianinh27@gmail.com \\ khasanah@iainponorogo.ac.id
}

\begin{abstract}
The objective of this research was to find out whether there is any significant difference vocabulary mastery between students who used socrative application for formative assessment and who are not used socrative application for formative assessment. This research applied quantitative research approach and used quasiexperimental design. In this research, the researcher used two classes (experimental class and control class) as a sample. The population of eleventh science grade in SMA Muhammadiyah 1 Ponorogo was 115 students. The number of sample in this research was 30 students of experimental class (XI IPA4) and 31 students of control class (XI IPA3). The researcher used simple random sampling to choose the sample in this research. The data were obtained by using a pre-test and post-test. The pre-test was given to both classes before the treatment and the post-test was given after the treatment. After getting the score of pre-test and post-test, the data were analyzed and processed by using T-test formula using SPSS 23 versions for Windows. The result of this research showed that the average of post-test of experimental class is 87.70 and the average score of post-test of control class is 77.74. The value of t-test $=$ 3,226 with $\mathrm{df}=59$ on level significance $5 \%$. According to the table value " $\mathrm{t}$ " $=1,671$. Then $t_{\text {count }}$ higher than $t_{\text {table }}(3,226>1,671)$. Therefore, $H_{1}$ is accepted and $H_{0}$ is rejected. So, it can be concluded that there is significant difference on students' vocabulary mastery that used socrative application for formative assessment and that are not. In the other words, Socrative Application is effective for formative assessment on students' vocabulary mastery of eleventh science grade of SMA Muhammadiyah 1 Ponorogo.
\end{abstract}

Keywords: socrative application, formative assessment, teaching vocabulary

\section{INTRODUCTION}

English has turn out to be a lingua franca. A lingua franca can be defined as a language that is adopted for conversation between two speakers whose native languages or using it as a second language (Harmer, 1997). It makes English as an international language that is learned many students in the world, not except in Indonesia.

In learning English, it always relates to the four skills. They are writing, speaking, reading and listening. Besides the four cores of language skills, the 
students should have well understanding of English component such as grammar and vocabulary to support their mastery of four language skills.

Vocabulary refers to a set of words for particular language or a list phrases that individual speaker of language use (Hatch \& Brown, 1995). Vocabulary is the most important aspect in English teaching and learning. We can't understand English without vocabulary. And also we can't understand about English spoken and written while we have no vocabulary. Based on this fact, vocabulary is not just very important aspect in learning English, but the most important aspect in learning English.

To measure students' vocabulary mastery, an English teacher needs to do an assessment in the end of English teaching learning process. However, the students usually don't interest while formative assessment process and it can influence to their achievement in vocabulary mastery.

Based on the researcher's preliminary study in SMA Muhammadiyah 1 Ponorogo on October, $24^{\text {th }} 2019$, the researcher found some students of XI IPA 4 had low motivation and feel uninterested in English teaching and learning especially in formative assessment process. They didn't give their best performance while doing the task from teacher. Because of their uninterested and low motivation while formative assessment, it can influenced to their achievement in vocabulary mastery. Almost $40 \%$ students of XI IPA 4 had limited vocabulary mastery. Whereas, SMA Muhammadiyah 1 Ponorogo was one of favorite school in Ponorogo and it was a school that had a good reputation and A grade acreditation. SMA Muhammadiyah 1 Ponorogo was also one of few school in Ponorogo that had billingual program.

One of many suitable solution that can be choosen to increase students' interesting while formative assessment is by using mobile learning. Mobile learning can be defined as electronical media devices such as the smartphone, computer, laptops that used in language learning. Mobile learning can increase the mobility of learners, the learners can learn everytime and everywhere (Gangaiamaran \& Pasupathi, 2017). With portable and personal mobile devices, learners can be engaged more flexible and accessible in learning practices without constraint on places.

From the reason above, one of mobile learning application that can be used to doing formative assessment is socrative application. Socrative application is one of the popular student online response systems that empower teachers to engage their students in classroom activities by using a quiz (Maslawati, 2019). It is considered as a appropriate application that can be used to increase students' motivation in formative assessment. According to relevant research about MobileAssisted Language Learning (MALL) defined that socrative application not only can enhance students' English ability but also increase students' learning motivation. Seemingly, it is helpful and efficient for students using socrative application for formative assessment.

Socrative application can facilitate teacher's question-giving and answersreceiving tasks. Using this application, all students can answer several questions very fast and the teacher knows the answers immediately. This application also has the following advantages, it is not neccessary to use neither any software nor 
any extra electronic device, its only needs smartphones with connection to internet. This application also can facilitate the cooperative learning strategy more efficiently (David Mendez Coca and Josip Slisko, 2013).

There are some previous research that study about the use of socrative application for classroom engagement. Based on journal from Laura Tirlea, Department of Psychological Sciences, Swinburne University of Technology. The title is "The Use of Socrative in Promoting Classroom Engagement: a Qualitative Investigation". She study about integrating socrative application into the statistics course changes the dynamic of the class and resulted in greater engagement, interaction and fun. Socrative application has a positive impact on students' engagement and interaction in class. Therefore, it is different with this research (Tirlea, 2018). In this research, the researcher focuses on the use of socrative application for formative assessment in teaching vocabulary.

The other previous research is a journal from Sam M Dakka, Sheffield Hallam University in title "Using Socrative to Enhance in-Class Student Engagement and Collaboration" also study about how using socrative application to assess the performance and engagement of students are enhanced as compared to traditional or other blended teaching and learning process. This research showed that using this student paced assessment (socrative application) despite the lack of collaboration aspects designed into the experiment did enhance the performance of the students on semester 2 as compared to semester 1 . In the other word, it can be said that socrative application can improve students vocabulary mastery and enhanced student engagement (Sam M Dakka, 2015).

Therefore, the researcher interested to conduct the research with the title "The Effectiveness of Socrative Application for Formative Assessment in Teaching Vocabulary at SMA Muhammadiyah 1 Ponorogo"

\section{METHODS}

In this research, the researcher applied experimental research method. Experimental research was a research that used experiment as a way to find the data and balancing of several features including validity, practicality and cost (Howard J Seltman, 2018). Experimental research was chosen because it was the best quantitative design to determine probable cause and effect.

Because of this research used experimental research method, so the best research design that can be used was quasi-Experimental research design. QuasiExperimental research design was signed by the researcher assigned randomly different treatments to both different classes (Mohammad Adnan Latief, 2012).

In this research, the researcher observed the ability population of the research, and then selected two classes out of all the existing classes which are of equivalent level. Next, the researcher randomly selected one of the classes into experimental group and the other one into the control group.

The process of data collecting technique includes pre-test, experimental treatment and post-test. Firstly, pre-test was given before experimental treatment to measure students' vocabulary mastery. For experimental treatment, the researcher applied socrative application for formative assessment in the experimental class and used paper based evaluation in the control class. Post-test 


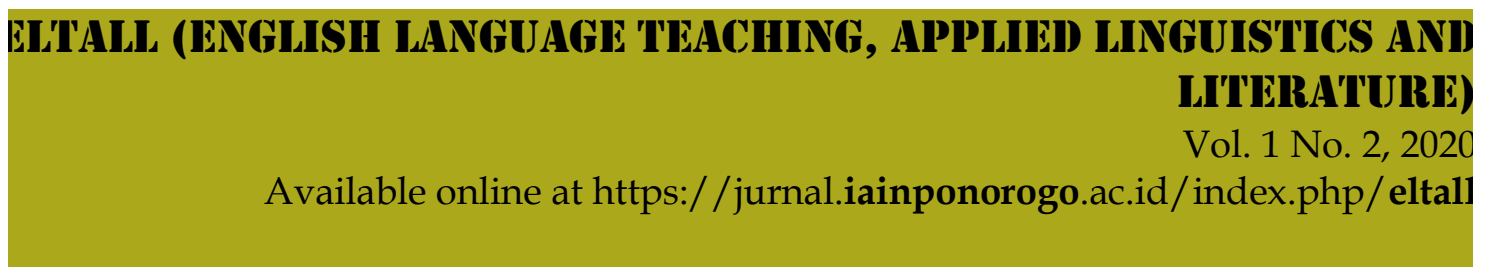

was given after experimental treatment both of classes to know students' vocabulary mastery progress. And the last, the researcher compared the result pretest and post-test between both of clasess.

\section{FINDING AND DISCUSSION}

Table 1

The Result of Mean Score of Experimental Class and Control Class

\begin{tabular}{|c|c|c|c|c|}
\hline \multicolumn{5}{|c|}{ Group Statistics } \\
\hline & Class & $\mathrm{N}$ & $\begin{array}{c}\text { Mean Score } \\
\text { Pre-test }\end{array}$ & $\begin{array}{c}\text { Mean Score } \\
\text { Post-test }\end{array}$ \\
\hline Result & $\begin{array}{l}\text { Experimental } \\
\text { Control }\end{array}$ & $\begin{array}{l}30 \\
31\end{array}$ & $\begin{array}{l}69,000 \\
70,000\end{array}$ & $\begin{array}{l}87,700 \\
77,742\end{array}$ \\
\hline
\end{tabular}

Based on the table above, the result of data analysis shows that the mean score pre-test of experimental class (students who used socrative application) is 69,000 and the mean score pre-test control class (students who used paper based assessment) is 70,000. While, the mean score posttest of experimental class is 87,700 and the mean score posttest of control class was 77,742 . It means that there are any different mean score between experimental and control class.

Before doing analysis data to determine whether the data have normal distribution or not and also to compute how the random variable is to be normally distributed, the researcher doing normality test. The result of experimental class's normality test by using Kolmogrov Smirnov (SPSS 23) is 0,053. The data can be said normally distributed if the sig $>0,05$. This sig. value is $0,053>0,05$. It means that the data from experimental class is normally distributed. While, the result of control class's normality test by using Kolmogrov Smirnov (SPSS 23) is 0,200 . The data can be said normally distributed if the sig $>0,05$. This value is $0,200>0,05$. It means that the data from control class is normally distributed.

Homogeneity test in experimental research is used to know whether control group and experimental group that are taken from population have same variance or not. Based on the calculation, the value of homogeneity test is 0,098 . Therefore, the data can be said homogeneous if the sig $>0,05$. This value is $0,098>0,05$. It means that the data from experimental class and control class were homogeneous.

To analyze the data in this research, the researcher used T-test. It is used to compare the students' vocabulary mastery between two class which used socrative application for formative assessment and not. 


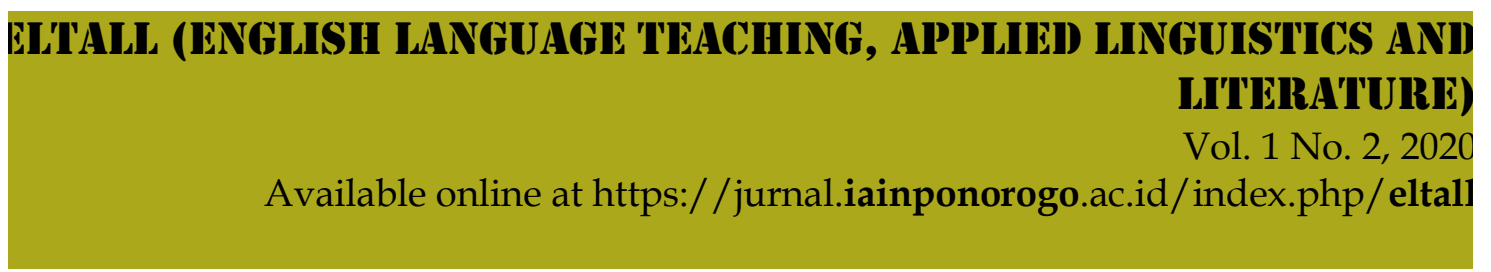

Table 2

The Result of T-Test Calculation and Independent Sample Test

Independent Samples Test

\begin{tabular}{|c|c|c|c|c|c|c|c|c|c|c|}
\hline & \multicolumn{2}{|c|}{$\begin{array}{l}\text { Levene's } \\
\text { Test for } \\
\text { Equality of } \\
\text { Variances }\end{array}$} & \multicolumn{7}{|c|}{ t-test for Equality of Means } \\
\hline & & \multirow[b]{2}{*}{$\mathrm{F}$} & \multirow[b]{2}{*}{ Sig. } & \multirow[b]{2}{*}{$\mathrm{T}$} & \multirow[b]{2}{*}{ Df } & \multirow{2}{*}{$\begin{array}{l}\text { Sig. } \\
(2- \\
\text { tail } \\
\text { ed })\end{array}$} & \multirow{2}{*}{$\begin{array}{l}\text { Mean } \\
\text { Differ } \\
\text { ence }\end{array}$} & \multirow{2}{*}{$\begin{array}{l}\text { Std. } \\
\text { Error } \\
\text { Differe } \\
\text { nce }\end{array}$} & \multicolumn{2}{|c|}{$\begin{array}{c}\text { 95\% Confidence } \\
\text { Interval of the } \\
\text { Difference }\end{array}$} \\
\hline & & & & & & & & & Lower & Upper \\
\hline \multirow[t]{2}{*}{$\begin{array}{l}\text { Hasi } \\
l\end{array}$} & $\begin{array}{l}\text { Equal } \\
\text { varian } \\
\text { ces } \\
\text { assum } \\
\text { ed }\end{array}$ & $\begin{array}{r}14,01 \\
6\end{array}$ & $\begin{array}{r}, 00 \\
0\end{array}$ & $\begin{array}{r}3,22 \\
6\end{array}$ & 59 & $\begin{array}{r}, 00 \\
2\end{array}$ & $\begin{array}{r}9,958 \\
1\end{array}$ & 3,0867 & 3,7816 & 16,1345 \\
\hline & \begin{tabular}{|l} 
Equal \\
varian \\
ces not \\
assum \\
ed
\end{tabular} & & & $\begin{array}{r}3,25 \\
5\end{array}$ & $\begin{array}{r}46,71 \\
4\end{array}$ & $\begin{array}{r}, 00 \\
2\end{array}$ & $\begin{array}{r}9,958 \\
1\end{array}$ & 3,0590 & 3,8032 & 16,1129 \\
\hline
\end{tabular}

Based on the result of t-test in the table above, the value of sig. (2-tailed) was 0,002 . It means that sig. ( 2 -tailed) $<0,05$. So, it can be used to get the basis decision in independent sample t-test. Based on the basis of getting decision in independent sample t-test, if sig. (2-tailed) $<0,05 \mathrm{H}_{0}$ is rejected and $\mathrm{H}_{1}$ is accepted. So, it can be concluded that there are any significant different score between students who use socrative application for formative assessment and student who didn't use socrative application for formative assessment

Then, the table above also shows the mean difference is 9,9581, it refers to average different of students score in experimental class and control class with the confidence interval different is 3,7816 to 16,1345 (95\% Confidence interval of the difference lower upper). $\mathrm{T}$ value is the result of $\mathrm{t}$ test $=$ Degree of freedom $(\mathrm{df})=\mathrm{n}-2$ $(61-2=59)$. The research result, $t=3,226$, with $\mathrm{df}=59$ on level significance $5 \%$. According to the value $t_{\text {table }}=1,671$. It means that $t_{\text {count }}>t_{\text {table }}=3,226>1,671$.

From the calculation above, it was shown that the difference coefficient of students who used socrative application for formative assessment and students who were not used socrative application for formative assessment is 3,226.

Hypothesis test $\left(\mathrm{t}_{0}\right)$ at 3,226 from the calculation above would be compared to the " $\mathrm{t}$ " index $(\mathrm{t} t)$ with condition below:

1. If the $t_{0}>t_{t}, H_{1}$ was accepted. It means that there was a significant difference between two variables.

2. If the $t_{0}<t_{t}, H_{1}$ was refused. It means that there was no significant difference between two variables. 


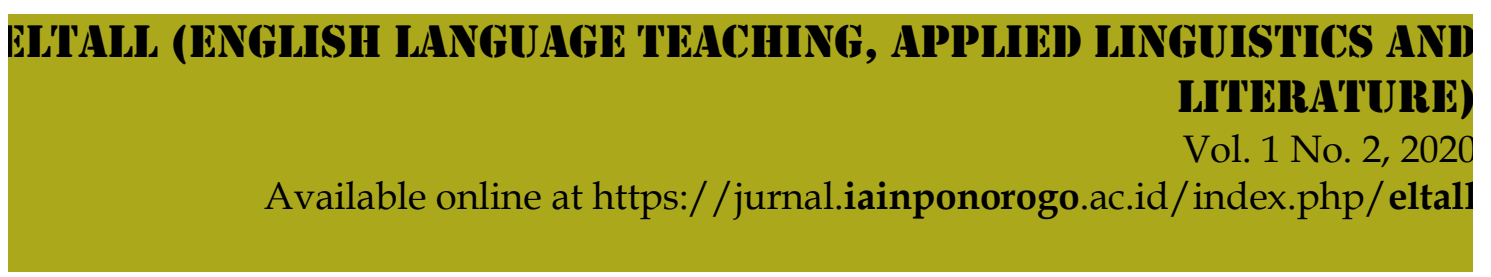

The calculation of $(\mathrm{df})=\mathrm{n}-2(61-2=59)$ is 59 . According to the table value " $\mathrm{t}_{\mathrm{t}}$ " with $\mathrm{df}=59$ on level significance $5 \%$ is 1,671 . Then the research result, $t_{0}=3,226$, so $t 0>$ tt $(3,226>1,671)$. It means that $\mathrm{H}_{1}$ is accepted and $\mathrm{H}_{0}$ is rejected. From the calculation above, it can be seen that the students who used socrative application for formative assessment got better score than the students who were not used socrative application for formative assessment.

According to Terrion and Aceti (2012), using Student Response System (Socrative application) and technology based systems can enhance students' engagement, where students can give an immediate feedback to the teacher questions.

According to Ismail El Mahdi, Abdulghani Al-Hattami and Hala Fawzi (2018), using technology based tools, such as Socrative application enhances formative assessment and consequently improves students' learning. The students' engagement is improved when the teacher uses socrative application for formative assessment which leads to creating effective teaching and learning environment.

So, it can be concluded that there is any significant difference score in vocabulary mastery between students who used socartive application for formative assessment and who aren't use socrative application at the eleventh science grade students of SMA Muhammadiyah 1 Ponorogo.

\section{CONCLUSION}

Based on data analysis, the researcher concluded that there was a significant different score on students' vocabulary mastery between students who used socrative application and paper based assessment for formative assessment in the eleventh grade students of SMA Muhammadiyah 1 Ponorogo. The students who are used socrative application for formative assessment got a better score than those who are not. The result of average score of post-test showed that experimental group or students who used socrative application for formative assessment $(87,70)$ is higher than control group or students who didn't used socrative application for formative assessement $(77,74)$.

It has been found that comparison between students' vocabulary score who used socrative application for formative assessment and who are not is 3,226 . This score is higher than $\mathrm{T}_{\text {table }}$ which is 1,671 at the level significant $5 \%$ and $\mathrm{db}=59$. It means that $\mathrm{H}_{1}$ is accepted and $\mathrm{H}_{0}$ is rejected. In the other words, socrative application is effective for formative assessment in teaching vocabulary.

\section{REFERENCES}

Coca, David Mendez and Josip Slisko. "Software Socrative and Smartphones as Tools for Implementation of Basic Processes of Active Physics Learning in Classroom: An Initial Feasibility Study with Prospective Teachers." European Journal of Physics Education, Vol 4. 2013.

Ehmadi, Ismail, Abdulghani Al-Hattami and Hala Fawzi. "Using Technology for Formative Assessment to Improve Students' Learning." The Turkish Online Journal of Education Technology (TOJET). 2018. 
Gangaiamaran, Ramya and Madumathi Pasupathi. "Review on Use of Mobile Apps for Language Learning." International Journal of Applied Engineering Research. Tamil Nadu: Research India Publication, 2017.

Harmer, Jeremy. The Practice of English Language Teaching Third Edition. London: Pearson Longman, 1997.

Hatch, Evelyn and Cheryl Brown. Vocabulary, Semantics, and Language Education. New York: Cambridge University Press, 1997.

Latif, Mohammad Adnan. Research Methods on Language Learning: An Introduction. Malang: University of Malang Press, 2012.

Maslawati, Mohammad. "Socrative in Teaching Tenses: Indonesian Students and Lecturers' Perception." Creative Education. 2019.

Seltman, Howard J. Experimental Design and Analysis. Carnegie: Carnegie Mellon University, 2018.

Terrion, J. L. \& V. Aceti, "Perceptions of the Effects of Clickers Technology on Student Learning and Engagement: a Study of Freshmen Chemistry Students." Research in LearningTechnology. 2012.

Tirlea, Laura et al. "The use of Socrative in Promoting Classroom Engagement: a Qualitative Investigation." ICOTS. 2018. 